\title{
Sun-exposed Site
}

National Cancer Institute

\section{Source}

National Cancer Institute. Sun-exposed Site. NCI Thesaurus. Code C129465.

An area of the body exposed to sunlight. 